\title{
The Determinants of Chief Executive Officer Compensation in Jordanian Industrial Corporations
}

\author{
Suzan Abed ${ }^{1}$, Mishiel Suwaidan ${ }^{2} \&$ Samiha Slimani $^{3}$ \\ ${ }^{1}$ Department of Accounting, Applied Science Private University, Amman, Jordan \\ ${ }^{2}$ Department of Accounting, Yarmouk University, Irbid, Jordan \\ ${ }^{3}$ Department of Accounting, M'hamed Bouguerra University, Boumerdès, Algeria \\ Correspondence: Suzan Abed, Department of: Accounting, Applied Science Private University, Amman (11931)- \\ P.O. Box 166, Jordan. Tel: 962-6560-9999-1558. E-mail: s_abed@asu.edu.jo
}

Received: August 21, 2014

doi:10.5539/ijef.v6n12p110
Accepted: September 11, $2014 \quad$ Online Published: November 25, 2014

URL: http://dx.doi.org/10.5539/ijef.v6n12p110

\begin{abstract}
The main objective of the study is to investigate factors that may affect the CEO compensation in developing countries namely in Jordan. In order to achieve this objective, a sample of 266 industrial companies listed on the Amman Stock Exchange during the period 2005-2010 was used to examine the determinants of compensation of CEO. The findings of regression analysis revealed that CEO compensation is strongly affected by company's size and CEO tenure, where CEOs with long tenure or in large firms are more compensated. Results also showed that the board of directors is influenced by the presence of the CEO among them in deciding his/her compensation. However, results revealed a significant inverse relationship between CEO age and CEO compensation. This result is largely consistent with many of the guidelines for improving corporate governance that have been recently promulgated by various groups.
\end{abstract}

Keywords: CEO compensation, executive compensation, determinants, tenure, managerial incentive, Jordan

\section{Introduction}

Compensation paid to the top executive manager is a major issue and a sensitive area in corporate finance. Corporations argue that they need to pay well to attract and motivate qualified people. Some argue that the amount paid is the most important element, while others argue that what matters is not how much to pay but how to pay it (Jensen \& Murphy, 1990).

A modern corporation is a team effort involving a number of players such as managers and shareholders (Brealey \& Myers, 2003). Jensen and Meckling (1976) identified the conflict of interest between managers and owners and how a company attempts to overcome such conflicts. The agency relationship is defined as "a contract under which one or more persons (principal (s)) engage another person (the agent) to perform some service on their behalf, which involves delegating some decision making authority to the agent", (Jensen \& Meckling, 1976, p. 5). In both public and private capital markets, individuals who do not have either skills or the desire to manage the business meet individuals who have good ideas or products and may not have the funds necessary to bring those products to the market. Separation of ownership from management function leads to conflict of interest between managers and owners because they have different concerns (Jensen \& Meckling, 1976). Owners are interested in maximizing the firm value while managers are interested in the maximization of their well-being (maximization of wealth and minimization of efforts). So managers may not manage in a value maximization way, they might pass up profitable investments because taking those investments requires more efforts from their part.

Several economists developed different theories to explain how the top manager should be compensated to avoid those conflicts mentioned by Jensen and Meckling. For example, Lazer and Rosen (1981) announced tournament theory which treats pay as a prize; the first prize in the tournament is received by the highest ranking position in an organization which is CEO position. Executive compensation is set to provide incentives not only to the executives, but also to their subordinates. The incentive is for lower-level executives to work hard, win the tournament and be promoted. Thereby they will receive that level of compensation, when the top price is set at a disproportionately high level; it has the effect of lengthening the career ladder of high managers. Rosen (1986) argued that top prizes of a disproportionate size are necessarily to motivate tournament survivors so that they do 
not rest on past achievements as they enter the final contest. Tournament theory also suggests that greater compensation gap between the tournament winner (top executive) and the remaining executives can be an effective mechanism to lower the monitoring cost, and align the interest between principals and agents. Therefore, tournament theory predicts a positive relationship between compensation gap and firm performance.

On the other hand, equity theory argues that executives' rewards should be distributed according to the level of their contribution to the organization (Gerhart et al., 2005). And to determine how fair they perceive their relationship to be, they should compare their return-contribution ratio to others inside and outside the organization. The violation of this expectation will result in feeling of inequity (Gerhart et al., 2005). A CEO will perceive a pay inequity when his/her compensation is not equal to that of other CEOs who have the same managerial capabilities. According to Adams (1963), a person perceives inequity when he/she is overpaid as well as when he/she is underpaid. Adams found that recipients of overpayment rarely perceive the payment as excessive because the threshold of overpayment is high and people tend to quickly restore equity by cognitively revaluating their own capabilities.

Not only in practice, but also in theory, the debate on what determines executive pay levels is still unending. Although many different theories are used to explain executive pay, the field is still dominated by agency theory as introduced by Jensen and Meckling (1976). A great deal of empirical studies has been conducted in this manner. Some of them tried to cover the determinants of the CEO compensation package while others related to the executive compensation to corporate performance. The objective of this study is to investigate how some variables affect the CEO compensation; i.e. how does the board size affect the compensation given to the CEO; does the belonging of the CEO to the board of directors make him/her get more compensation; do all of the CEO age, his/her tenure and ownership in the company affect his/her compensation and do institutional ownership influence the $\mathrm{CEO}$ rewards.

The remainder of this paper is organized into five sections. Section 2 reviews empirical studies of determinants of board compensation and develops the study hypotheses. Section 3 describes methodology employed in the current paper. Section 4 presents the results of the study. Section 5 summaries the main conclusion of the study and provides recommendation for the study.

\section{Literature Reviews and Hypotheses Development}

This section provides a review of previous studies relevant to the current study. For example, Gomez-Mejia et al. (1987) analyzed the effect of ownership of the firm on executive compensation in 17 companies listed on the Standard and Poor's COMPUSTAT during the period 1979-1982. Using various measures of returns and firm size, they created a two-factor model and found that in firms of which at least $5 \%$ of the shares was owned by an individual or organization (owner-controlled firm) and performance were significant predictor of CEO compensation. In contrast, in firms where no entity held as much as $5 \%$ of the shares and size were significant predictor for executive remuneration. They concluded that "outside dominant" stockholders had the power and the motivation to align CEO compensation with the organization's performance.

Carr (1997) examined the effect of some variables on chief executive officer (CEO) compensation in 31 small firms during the period 1987-1992. She found that conventional performance measures such as sales, profitability (measured by return on equity), and risk played a significant role in explaining the movements in CEO compensation. The empirical evidence that she presented did not support the hypothesis that suggests the stronger the role of insiders on the board is, the weaker the link between organizational outcomes and executive compensation will be. Furthermore, the study found no significant relation between ownership interest of the board members and CEO compensation in small publicly traded firms.

Eriksson (1999) investigated some aspects of tournament theory for a data containing information about 2600 executives in 210 Danish firms during a period 1992-1995. The result found a stable convex relation between pay and job levels. That is, the larger the number of managers having significant responsibilities in the firm is, the larger the wage spread would be. Thus, the prediction of tournament model is supported.

Core et al. (1999) examined the relation between executives compensation and both board characteristics and ownership structure, using 495 observations during a period 1982-1984 for 205 publicly traded US firms. The results concluded that measures of board and ownership structure explained a significant amount of cross-sectional variation in CEO compensation. Furthermore, the study examined whether the observed association between executives' compensation and board and ownership structure variables are proxied for the effectiveness of corporate governance structure. The results also found that the predicted component of compensation arising from these characteristics of board and ownership structure had a statistically significant negative relation with subsequent firm operating and stock return performance. This result suggested that firms 
with weaker governance structures have greater agency problems. On the other hand, Elloumi and Gueyié (2001) investigated the relationship between CEO compensation and investment opportunity set (IOS) using a sample of 415 Canadian firms for 1997. The Finding showed that firms with high IOS pay higher levels of total compensation to their CEOs.

Recently, some studies witness the importance of regulation, for instance, Nourayi and Daroca (2008) examined the impact of regulation, size, market returns, accounting returns, number of employees, and nature of the business in terms of new-economy vs the traditional one on both CEO cash compensations and total compensations using a sample of 455 US firms during the period 1996-2002. The results found that size and market returns were the most significant explanatory variables for both cash and total CEO compensations. Accounting returns were significant explanatory variables for CEO cash compensations with regulated and new economic firms. Changes in the employees' number were significant for CEO cash and total compensations with non-regulated firms.

Gu and Kim (2009) investigated the determinants of cash compensation for chief executive officers (CEOs). The study contained 53 firm year observations from 2002 to 2004 of publicly traded US airlines. The result documented that the airline CEO cash compensation was positively correlated with only the size and revenue efficiency of an airline firm; CEOs in large airlines are greater compensated than their colleagues in the small ones because large firms are more complex, so they need more efforts to be done by the CEO. The positive relation with revenue efficiency means that the pay-for-performance principle has been to some extent adhered to in determining CEO cash compensation.

Shah et al. (2009) explored the determinants of CEO Compensation for 114 companies listed on the Karachi Stock Exchange for the period from 2002-2006. The results indicated that company size was found to be significantly and positively related to CEO compensation. Also, alternative proxies for Corporate Governance (ownership structure, ownership concentration and audit committee independence) were significantly correlated with CEO Compensation.

Jiang et al. (2009) investigated the impact of ownership concentration on CEO compensation and firm performance relationship using a sample of New Zealand listed companies during the period 2001 to 2005. Regression results revealed a non-linear effect of ownership concentration on CEO compensation-firm performance relationship. That is high (low) ownership concentration was negatively (positively) associated with CEO compensation-firm performance relationship. At high ownership concentration level, large controlling shareholders seem dysfunctional in shortening managerial power. On the other hand, low level of ownership concentration significantly increases the CEO compensation and firm performance association, suggesting a more efficient large shareholders' monitoring on corporate governance.

Lee and Chen (2011) examined the determining factors of CEO compensation and the relationships between CEO compensation, CEO ownership and the firm value. Relying on data from publicly traded Taiwan firms during the period 1995-2004 and applying a two-stage least squares regression for the panel data model. The results indicated that CEO compensation was positively associated with firm size, board size, institutional ownership, and performance. However, R\&D expenditure, firm age and firm risk have significant negative effect on CEO compensation. Additionally, the results of simultaneous equation revealed that CEO compensation, CEO ownership and firm value were interdependent. That is, CEO compensation was positively related to both CEO ownership and firm value while this latter was negatively related to CEO ownership.

Wang et al. (2013) examined the level and structure of CEO compensation of 2,448 CEO's from 1,622 firms for the period 1997-2002. The results found that the higher degree of international diversification, higher accounting earning performance, higher investment opportunities, and larger firm size, resulted in CEO's receiving higher levels of compensation.

Most of previous studies on management compensation have been conducted in developed countries. Not too many numbers of studies have been conducted in developing countries. In an attempt to provide broader picture of the issues on hand, the current study achieves the above objective by conducting the research in the context of developing country, particularly Jordan in order to raise our understanding of un-discussed issues. Based on the previous empirical studies, it can be hypothesized that CEO determinants are associated with alternative variables namely; CEO tenure, CEO age, company age, board size, CEO age, role duality, institutional ownership and CEO ownership.

\subsection{CEO Tenure}

Executive tenure has received some attention among the investigators of executive compensations (e.g., Chung 
\& Pruitt, 1996; Lee \& Chen, 2011). Chief executives with high tenure may receive higher compensations because they may be better able to influence the board of directors (Chung \& Pruitt, 1996). Zheng (2010) measured CEO's tenure as the length of time in whole years since the CEO was on the position. Following these studies, the following hypothesis is formulated

H1: There is a significant positive association between the CEO tenure and his/her compensation.

\subsection{CEO Age}

Experience provides an important signal to managerial labor markets about an executive's likely future performance. It may increase the CEO's marketability (Smithey, 2009). When executives are mobile, tenure with any one particular organization is not necessarily a good approximation of experience; rather, cumulative experience may be better proxied by age (Smithey, 2009). Research focusing on executive career success has found age to be a stronger predictor of cash compensation than job or tenure (Smithey, 2009). According to Gibbons and Murphy (1992), older CEOs prefer cash compensation because of their shorter employment horizon.

On the contrary, managers' age may affect his/her attitude to risk in a way that younger managers bear more risk in taking decisions whereas older managers tend to be more conservative. Thus, CEOs might be insured against bearing risk of risky projects by demanding high compensation (Hambrick \& Mason, 1984). The following hypothesis is set:

H2: There is a significant negative relationship between the CEO age and his/her compensation.

\subsection{Company Age}

Various CEO and firm characteristics may be different among with different ages. For example, company's growth, size, CEO age may systematically vary according to the age of the firm. Chung and Pruitt (1996) and Chosh (2003) found negative relation between CEO compensation and company age. Consistent with previous studies, it can be hypothesized that:

H3: There is a significant negative relationship between the company age and his/her compensation.

\subsection{Board Size}

The board size has been identified as an important determinant of corporate governance effectiveness in theoretical and empirical studies (e.g., Coughlan \& Schmidt, 1985; Jensen, 1993). As the size of the board increases, the monitoring ability of the board of directors will be ineffective and more susceptible to the influence of CEOs (Core et al., 1999; Lee \& Chen, 2011). Furthermore, when the board size is large, it is difficult to form coalitions opposing the CEO (Cahan et al., 2005). Consistent with previous research the following hypothesis is formulated:

H4: There is a significant positive association between the board size and the compensation given to the CEO.

\subsection{Role Duality}

Boards of directors and CEOs differ in their power and preferences, and so compensation reflects those differences. The relative power of the CEO has often been traced to a lack of board caution, which in turn has been found to be correlated with board composition (Elloumi \& Gueyié, 2001). Prior research has focused on duality in evaluating the influence that the board exerts in setting CEO compensation. A single individual serving as both CEO and chair of the board may have more power, and therefore CEO interests may dominate shareholders' interests (Elloumi \& Gueyié, 2001). Being in line with these studies, the following hypothesis is formed:

H5: There is a significant positive association between role duality and CEO compensation

\subsection{Institutional Ownership}

The existence of institutional ownership is considered as one of the effective monitoring mechanisms which may reduce the agency conflict by monitoring managerial actions. Institutional investors not only have the motivation and duty to monitor CEO compensation, but they also have the expertise and resources to do so (Lee \& Chen, 2011). Chen and Firth (2005) suggested a negative relationship between institutional ownership and CEO compensation because institutional owners provide better governance in setting a compensation policy. Based on the above, the following hypothesis is formed:

H6: There is a significant negative association between institutional ownership and CEO compensation. 


\subsection{CEO Ownership}

Senior executive ownership may impact compensation (Finkelstein \& Hambrick, 1989; Gomez-Mejia \& Balkin, 1992). Wright and Kroll (2002) find that in firms where CEOs have large ownership, CEOs might be higher compensated. Being in line with previous research, the following hypothesis is formed.

H7: There is a significant positive association between CEO ownership and CEO compensation.

\subsection{Control Variables}

Size has been proposed in the literature as significant variable in explaining variations in the compensation of CEOs (e.g., Gomez-Mejia et al., 1987; Core et al., 1999; Gu \& Kim, 2009; Lee \& Chen, 2011). They proposed that large firms are more complex, thus, they necessitate hiring high-quality executives at high pays. Additionally, firm performance has been considered to be an important determinant of CEO compensation (Murphy, 1985; Jensen \& Murphy, 1990). The literature on CEO compensation emphasizes that executive compensation should be given on the basis of performance. Moreover, in corporate finance, debt has been proposed as an agency problem control mechanism (Jensen, 1986). Debt lowers financial slacks, alternatively diminishes managerial discretion (Wright \& Kroll, 2002). Moreover, Gu and Kim (2009) suggested that leverage deters firms from offering excessive compensation. Based on the above, company's size, performance and leverage have been added to factors that may affect CEO compensation.

\section{Research Methodology}

This section presents the sample employed in the study and the research model employed to test for the study hypotheses.

\subsection{Sample of the Study}

The population of this study consists of all Industrial Corporation listed on the Amman Stock Exchange (ASE) during the period 2005-2010. Thus, based on a sample of 70 listed industrial companies, the total number of observations is 420 (company/year). However, the final number of observations employed by the study is 266 companies. This variation in the number of observation is attributed to the fact that some annual reports do not contain all the requested information, particularly information on the board of directors and CEOs compensations. Also, some of annual reports are missing during the period of the study.

\subsection{Regression Model}

The following Pooled Ordinary Least Squared (OLS) regression model is used to examine the impact of a number of explanatory variables on CEO compensation, includes year-specific intercepts to reflect the fact that the population may have different distributions in different time periods. This is accomplished by including dummy variables for all with except of one year.

$$
\begin{gathered}
\mathrm{COMP}=\beta_{0}+\beta_{1} \text { TENR }+\beta_{2} \text { DUAL }+\beta_{3} \text { AGE }+\beta_{4} \text { Bsize }+\beta_{5} \text { INS }+\beta_{6} \text { CAGE }+\beta_{7} \text { OWN }+\beta_{8} \text { Size }+\beta_{9} \text { ROA }+ \\
\beta_{10} \text { Debt }+\beta_{11} \text { YearEnd05 }+\beta_{12} \text { YearEnd06 }+\beta_{13} \text { YearEnd07 }+\beta_{14} \text { YearEnd08 }+\beta_{15} \text { YearEnd09 }+\varepsilon
\end{gathered}
$$

Where:

COMP: Natural log of the annual salary and bonus given to the CEO in JD;

$\beta_{0, \ldots . .} \beta_{15}$ : Regression coefficient;

TENR: Number of years the CEO spends in his position as a CEO;

DUAL: Dummy variable that equals 1 if the CEO belongs to the board of directors and 0 otherwise;

AGE: The Chief Executive Officer's age;

Bsize: Number of directors in the board;

INS: Percentage of shares owned by institutions;

CAGE: The number of years the company in work;

OWN: Percentage of shares owned by the CEO;

SIZE: Natural log of total assets;

ROA: Performance, calculated by net income to total assets;

Debt: Total debt to total assets;

YearEnd05: Take the value of 1 for the 2005 year-end firm observations, and 0 otherwise;

YearEnd06: Take the value of 1 for the 2006 year-end firm observations, and 0 otherwise; 
YearEnd07: Take the value of 1 for the 2007 year-end firm observations, and 0 otherwise;

YearEnd08: Take the value of 1 for the 2008 year-end firm observations, and 0 otherwise;

YearEnd09: Take the value of 1 for the 2009 year-end firm observations, and 0 otherwise;

E: Error term.

\section{Data Analysis and Discussion of Result}

This section presents the descriptive results of the study and also presents the results of hypotheses testing.

\subsection{Descriptive Statistics}

Table 1 presents a summary statistics for both; the dependent and independent variables used in the model of CEO compensation. The descriptive is curried out after the realization of the required modifications and changes (removal of outliers and log transformations).

Table 1. Descriptive statistics for dependent and independent variables

\begin{tabular}{lllllll}
\hline & Min & Max & Mean & Std. Dev & Skewness & Kurtosis \\
\hline COMP (JD)* & 14760 & 358890 & 70033.5 & 55727.5 & 2.16 & 5.99 \\
COMP (log) & 9.6 & 12.79 & 10.92 & 0.67 & 0.37 & -0.34 \\
TENR & 1 & 20 & 7.69 & 5.37 & 0.62 & -0.67 \\
DUAL & 0 & 1 & 0.62 & 0.49 & -0.51 & -1.75 \\
AGE & 33 & 79 & 52.84 & 10.38 & 0.24 & -0.7 \\
Bsize & 3 & 14 & 8.36 & 2.1 & -0.02 & -0.04 \\
INS & 0.55 & 99.98 & 47.72 & 24.74 & 0.09 & -0.51 \\
CAGE & 0.69 & 4.06 & 3.02 & 0.61 & -0.47 & 0.61 \\
OWN & 0 & 55.13 & 2.35 & 5.86 & 4.7 & 30.6 \\
DEBT & 0.44 & 88.74 & 34.13 & 19.98 & 0.61 & -0.03 \\
ROA & -20.8 & 35.66 & 1.43 & 8.4 & 0.09 & 1.3 \\
SIZE & 13.79 & 19.48 & 16.36 & 0.92 & -0.05 & 0.47 \\
CAGE & 0.69 & 4.06 & 3.02 & 0.61 & -0.47 & \\
\hline
\end{tabular}

Note. * COMP in JD is not used in the analysis.

It can be seen in this Table that, on average companies pay 70033.5 Jordanian Dinars yearly as compensation for its CEO, and the range is from a minimum of $14760 \mathrm{JD}$ to a maximum of 358890 . Moreover, this Table reveals that COMP after transformation and all independent variables with exception of OWN are normally distributed as indicated by Skewness and Kurtosis tests. The rule of thumb for normality test based on Skewness of \pm 1.96 and a Kurtosis of \pm 2 (Cooke, 1989). This means that the problem of normality no longer exists in the current study.

\subsection{Results of the Pooled Regression Analysis}

Before performing the pooled regression analysis, the data set comply with the pooled multiple regression assumptions (normality, collinearity, autocorrelation, homoscedasticity). Table 2 presents the results of pooled OLS regression analysis.

As seen from Table 2, the model is highly significant $(F=8.672, p=0.000)$ with an adjusted $\mathrm{R}$ square of 0.411 . Therefore, approximately $41 \%$ of the variation in the compensation given to the CEO is explained by the model.

For hypotheses testing, CEO tenure is found to be significant at a $1 \%$ level with positive coefficients $(t=3.332$, $\mathrm{p}=0.001)$. The positive coefficient of CEO tenure means that the more time the CEO spends in his/her position in a company, the more compensation he or she gets. It is possible that longer-tenured executives may be better able to influence their boards of directors, and by doing so, they achieve higher levels of compensation. This result is also achieved by the studies of Carothers (2004), Bertsch (2005) and Shah et al. (2009). 
Table 2. Results of the pooled regression model

\begin{tabular}{lllll}
\hline & B & T-value & P-Value & VIF \\
\hline Constant) & 6.035 & 5.313 & 0.000 & \\
TENR & 0.041 & 3.332 & 0.001 & 1.304 \\
Dual & 0.304 & 2.458 & 0.016 & 1.212 \\
Bsize & -0.004 & -0.138 & 0.890 & 1.225 \\
Age & -0.012 & -2.133 & 0.035 & 1.270 \\
INS & 0.001 & 0.499 & 0.619 & 1.335 \\
ROA & 0.007 & 0.736 & 0.464 & 1.239 \\
Debt & -0.003 & -0.804 & 0.423 & 1.241 \\
Size & 0.351 & 5.469 & 0.000 & 1.405 \\
Own & -0.010 & -1.049 & 0.297 & 1.224 \\
Cage & -0.219 & -1.881 & 0.063 & 1.175 \\
YearEnd05 & 0.126 & 1.146 & 0.477 & 1.314 \\
YearEnd06 & -0.007 & -0.059 & 0.678 & 1.205 \\
YearEnd07 & -0.003 & -0.377 & 0.434 & 1.209 \\
YearEnd08 & 0.075 & 0.335 & 0.323 & 1.185 \\
YearEnd09 & -0.035 & -0.449 & 0.211 & \\
\hline
\end{tabular}

Note. Adj R2 $=0.411 ; \mathrm{F}=8.672 ;$ Sig. $=0.000$.

Besides, CEO duality (influence) and CEO age are significant at a 5\% level $(\mathrm{t}=2.45, \mathrm{p}=0.016 ; \mathrm{t}=-02.133, \mathrm{p}=$ 0.035). CEO duality has a positive coefficient, which means that the board of directors is influenced by the presence of the CEO among them, and thus, they compensate him/her more. In other words, the CEO is more powerful when he/she belongs to the directors of the board who are responsible for setting his/her compensation. This result is the same as that found by Elloumi and Gueyié (2001). CEO age is negatively correlated with compensation, meaning that younger executives are more compensated than older ones. A possible explanation is that Jordanian companies show a greater tendency and eagerness to employ younger people who have recently graduated. To emphasize, nowadays' companies are interested in those who dispose of Certified Management Accountant (CMA) and Certified Financial Accountant (CFA) certificates, which begun to be spread among recent graduated people. This finding is the same as the one found by Hambrick and Mason (1984) who claim that younger managers bear more risk in taking decisions whereas older managers tend to be more conservative; thus, CEOs might be insured against bearing risk of risky projects by demanding high compensation.

For Company age, it is significant with a negative coefficient at a $10 \%$ level only $(\mathrm{t}=-1.801, \mathrm{p}=0.063)$, indicating that chief executives are better compensated in new companies than in mature ones. A possible justification is that by giving high compensation, a new company tries to attract competent and experienced managers to guarantee its continuance.

Moreover, the result shows significant relation with size. The fact that the coefficient of the firm size is positive indicates that CEOs in large companies are more compensated than their colleagues in small firms. A possible explanation is that large firms are more complex, thus they need high qualified managers who demand to be high compensated. This finding is the same as that found by Core et al. (1991), Wright and Kroll (2002), Gu and Kim (2009) and Lee and Chen (2011).

However, board size, institutional ownership, performance, leverage and CEO ownership have not been found to have statistically significant effect on CEO compensation.

\section{Conclusion}

The objective of this study was to investigate the determining factors of the chief executive officer compensation in Jordan. The pooled regression model identified that CEO tenure, role duality and firm size are found to be positively and significantly related to variation in the CEO compensation. However, among these variables, size is found to be the most powerful explanatory variable followed by CEO tenure. For other variables, CEO age and company age are found to be negatively and significantly related to CEO compensation at 5\% and $10 \%$ levels of significance respectively. From this finding, firms are recommended to change the CEO from time to time to avoid paying him/her a lot because tenure is positively related to the compensation. This result is largely consistent with many of the guidelines for improving corporate governance that have been recently promulgated by various groups. In particular, calls for improving corporate governance by separating the Chairman and CEO, 
relying on smaller boards, imposing mandatory retirement ages, are all consistent with previous studies.

\section{References}

Adams, J. S. (1963). Toward an Understanding of Inequity. Journal of Abnormal Psychology, 67, $422-436$. http://dx.doi.org/10.1037/h0040968

Bertsch, K., \& Mann, C. (2005). CEO Compensation and Credit Risk, Moody's Investor Service Global Credit Research, Special Comments.

Brealey, R. A., \& Myers, S. C. (2003). Principles of Corporate Finance (7th ed.). McGraw-Hill, Irwin.

Cahan, S. F., Chua, F., \& Nyamory, R. O. (2005). Board Structure and Executive Compensation in the Public Sector: New Zealand Evidence. Financial Accountability and Management, 21(4), 437-465. http://dx.doi.org/10.1111/j.0267-4424.2005.00228.x

Carr, L. L. (1997). Strategic Determinants of Executive Compensation in Small Publicly Traded Firm. Journal of Small Business Management, 35(2), 1-12.

Chan, M. (2008). Executive Compensation. Business and Society Review, 1, 129-161. http://dx.doi.org/10.1111/j.1467-8594.2008.00316.x

Cheng, S., \& Firth, M. (2005). Ownership, Corporate Governance and Top Management Pay in Hong Kong. Corporate Governance. An International Review, 13(2), 291-302. http://dx.doi.org/10.1111/j.1467-8683.2005.00423.x

Chosh, A. (2003). Determination of Executive Compensation in an Emerging Economy: Evidence from India. Indira Gandhi Institute of Development Research, India.

Chung, K. H., \& Pruitt, S. W. (1996). Executive Ownership, Corporate Value, and Executive Compensation: A Unifying Framework. Journal of Banking and Finance, 20, 1135-1159. http://dx.doi.org/10.1016/0378-4266(95)00039-9

Cooke, T. E. (1989). An Assessment of Voluntary Disclosure in the Swedish Companies. Accounting and Business Research, 19(74), 113-124. http://dx.doi.org/10.1080/00014788.1989.9728841

Core, J. E., Holthausen, R. W., \& Larcker, D. F. (1999). Corporate Governance, Chief Executive Officer Compensation, and Firm Performance. Journal of Financial Economics, 51(3), 371-406. http://dx.doi.org/10.1016/S0304-405X(98)00058-0

Coughlan, A., \& Schmidt, R. (1985). Executive Compensation, Management Turnover and Firm Performance: An Empirical Investigation. Journal of Accounting and Economics, 7, 43-66. http://dx.doi.org/10.1016/0165-4101(85)90027-8

Elloumi, F., \& Gueyié, J. P. (2001). CEO Compensation, IOS and the Role of Corporate Governance. Corporate Governance, 1(2), 23-33. http://dx.doi.org/10.1108/EUM0000000005487

Eriksson, T. (1999). Executive Compensation and Tournament Theory: Empirical Tests on Danish Data. Journal of Labor Economics, 17(2), 262-280. http://dx.doi.org/10.1086/209920

Finkelstein, S. (1992). Power in Top Management Team: Dimensions, Measurement, and Validation. Academy of Management Journal, 35(3), 505-538. http://dx.doi.org/10.2307/256485

Finkelstein, S., \& Hambrick, D. C. (1989). Chief Executive Compensation: A Study of the Intersection of Markets and Political Processes. Strategic Management Journal, 10(2), 121-134. http://dx.doi.org/10.1002/smj.4250100203

Gerhart, B., Minkoff, H., \& Olsen, R. (2005). Employee Compensation: Theory, Practice, and Evidence. Working Paper No. 95, Cornell University, NY, USA.

Gibbons, R., \& Murphy, K. J. (1992). Optimal Incentive Contracts in the Presence of Career Concerns: Theory and Evidence. Journal of Political Economy, 100(3), 468-505. http://dx.doi.org/10.1086/261826

Gomez-Mejia, L. R. (1992). Structure and Process of Diversification, Compensation Strategy, and Firm Performance. Strategic Management Journal, 13, 381-397. http://dx.doi.org/10.1002/smj.4250130506

Gomez-Mejia, L. R., \& Balkin, D. B. (1992). Compensation, Organizational Strategy and Firm Performance. $\mathrm{OH}$ : South West Publishing Co., College Division, Cincinnati.

Gomez-Mejia, L. R., \& Wiseman, R. M. (1997). Reframing Executive Compensation: An Assessment and Outlook. Journal of Management, 23(3), 291-374. http://dx.doi.org/10.1177/014920639702300304 
Gomez-Mejia, L. R., Tosi, H., \& Hinkin, T. (1987). Managerial Control, Performance, and Executive Compensation. Academy of Management Journal, 30(1), 51-70. http://dx.doi.org/10.2307/255895

Gordon, M. J. (1963). Optimal Investment and Financing Policy. The Journal of Finance, 18, $264-272$. http://dx.doi.org/10.2307/2977907

Grabke-Rundell, A., \& Gomez-Mejia, L. R. (2002). Power as a Determinant of Executive Compensation. Human Resource Management Review, 12, 3-23. http://dx.doi.org/10.1016/S1053-4822(01)00038-9

Gu, Z., \& Kim, K. (2009). CEO Cash Compensation Determinants: An Empirical Examination of US Airlines. The Service Industries Journal, 29(7), 995-1005. http://dx.doi.org/10.1080/02642060902749823

Hambrick, D. C., \&. Mason, P. A. (1984). Upper Echelons: The Organizations as a Reflection of its Top Managers. Academy of Management Review, 9(2), 193-206. http://dx.doi.org/10.2307/258434

Jensen, M. C., \& Murphy, K. J. (1990). Performance and Top Management Incentives. Journal of Political Economy, 982, 225-264. http://dx.doi.org/10.1086/261677

Jiang, H., Habib, A., \& Smallman, C. (2009). The Effect of Ownership Concentration on CEO Compensation-Firm Performance Relationship in New Zealand. Pacific Accounting Review, 21(2), $104-131$. http://dx.doi.org/10.1108/01140580911002053

Lazear, E. P., \& Rosen, S. (1981). Rank-Order Tournaments as Optimum Labor Contracts. The Journal of Political Economy, 81(5), 841-864. http://dx.doi.org/10.1086/261010

Lee, S. P., \& Chen, H. J. (2011). Corporate Governance and Firm Value as Determinants of CEO Compensation in Taiwan. Management Research Review, 34(3), 252-265. http://dx.doi.org/10.1108/01409171111116286

Lin, B. X., \& Lu, R. (2009). Managerial Power, Compensation Gap and Firm Performance: Evidence from Chinese Public Listed companies. Global Finance Journal, 20(2), 153-164. http://dx.doi.org/10.1016/j.gfj.2008.12.002

Mehran, H. (1995). Executive Compensation Structure, Ownership, and Firm Performance. Journal of Financial Economics, 38, 163-184. http://dx.doi.org/10.1016/0304-405X(94)00809-F

Nourayi, M. M., \& Daroca, F. P. (2008). CEO Compensation, Firm Performance and Operational Characteristics. Managerial Finance, 34(8), 562-584. http://dx.doi.org/10.1108/03074350810874055

Rosen, S. (1986). Prizes and Incentives in Elimination Tournaments. American Economic Review, 701-715.

Shah, S. Z. A., Javed, T., \& Abbas, M. (2009). Determinants of CEO Compensation: Empirical Evidence from Pakistani Listed Companies. International Research Journal of Finance and Economics, 32, 148-159.

Smithey, F. I. (2009). The Elephant in the Room: Labor Market Influences on CEO Compensation. Personnel Psychology, 62, 659-695. http://dx.doi.org/10.1111/j.1744-6570.2009.01154.x

Sun, L. S., Zhao, X., \& Yang, H. (2010). Executive Compensation in Asia: A Critical Review and Outlook. Springer Science, 775-802.

Wang, H. C., Frostburg, C. V., \& Providence, Y. L. (2013). Determinants of Chief Executive Officer Compensation. The International Journal of Business and Finance Research, 7(4), 29-42.

Wright, P., \& Kroll, M. (2002). Executive Discretion and Corporate Performance as Determinants of CEO Compensation, Contingent on External Monitoring Activities. Journal of Management and Governance, 6 , 189-214. http://dx.doi.org/10.1023/A:1019676314682

Yermack, D. (1996). Higher Market Valuation of Companies with a Small Board of Directors. Journal of Financial Economics, 40(2), 185-211. http://dx.doi.org/10.1016/0304-405X(95)00844-5

Zheng, Y. (2010). The Effect of CEO Tenure on CEO Compensation: Evidence from Inside CEOs vs Outside CEOs. Managerial Finance, 36(10), 832-859. http://dx.doi.org/10.1108/03074351011070224

\section{Copyrights}

Copyright for this article is retained by the author(s), with first publication rights granted to the journal.

This is an open-access article distributed under the terms and conditions of the Creative Commons Attribution license (http://creativecommons.org/licenses/by/3.0/). 